\title{
サルモネラ Re 変異株由来糖脂質の化学処理 による生物活性の変化
}

\author{
天野 憲一 藤田浩* \\ 佐藤 年信* 佐々木博海* \\ 吉田 豊* 福土 主計

\section{弘前大学 医学部 細菌学講座} \\ *第一内科学講座 \\ 弘前市在府町 5 T036 \\ 〔受付：8月24日，1984年〕
}

\begin{abstract}
Salmonella minnesota $\operatorname{Re}$ 変異株よりフェノール: クロロホルム：石油エーテルで抽出した桾 脂質 (ReGl) をアルカリ $\left(0.1 \mathrm{~N}\right.$ 水酸化ナトリウムおよびアルカリ性 $\left.\mathrm{NH}_{2} \mathrm{OH}\right)$ あるいは弱酸 ( $\mathrm{pH} 4.5$ の酢酸ナトリウムおよび $0.1 \mathrm{~N}$ 塩酸) で処理を行い，それぞれの生成物の生物活性を 測定した。

O-エステル結合脂肪酸の完全脱離した ReGl- $\mathrm{NH}_{2} \mathrm{OH}$ はリムルス活性, 鶏卵致死毒性拉よび 発熱毒性すべてが消失または大きく減少した。一方, ReGl から還元端のリン酸基と KDO が 除かれた ReGl-HCl は鵴畉致死毒性と発熱毒性を失つたが、リムルス活性はそのままであっ た。さらに ReGl- $\mathrm{NH}_{2} \mathrm{OH}$ はマクロファーシ活性化能およびリンパ球幼若化能も大幅に減少し ていたが， ReGl-HCl はマクロファージ活性化能を保持していた。 ReGl- NaOH と ReGl-pH 4.5 は未処理の ReGl とほとんど変らない上記の生物活性を示した。

ラットのメチルコラントレン誘発腫瘏に対して, 未処理の ReGl と ReGl-HCl は約 $50 \%$ の治 愻率を示すのに比較して, ReGl- $\mathrm{NH}_{2} \mathrm{OH}$ は延命効果を示すのにとどまつた。
\end{abstract}

グラム陰性細菌の外膜に存在するリポ多糖 (Lipopolysaccharide；LPS) は一般に内毒素と呼ばれ，多岐にわ たる生物活性を有する。この LPS は抗腫瘲活性, アジ ユバント活性, インターフェロン誘発能, 腫瘍壊死因子 誘発能など, 臨床治療に応用可能な活性を持つ反面, 致 死毒性や発熱毒性に代表されるような毒性を常に持ち合 わせていることが，人体への応用の障害となつている。 Ribi を中心とするグループ2,10)が弱塩酸処理によつて毒 性を無くし，抗腫瘍性のみを残す方法を開発した。一 方, 福士ら゙)はヒドロキシルアミン $\left(\mathrm{NH}_{2} \mathrm{OH}\right)$ 処理によ つて同様の結果を得ている。

そこでわれわれは臨床への応用といらことを主眼にお いて, サルモネラ $\operatorname{Re}$ 変異株の内毒素である糖脂質 $(\mathrm{Re}$ glycolipid; ReGl) を化学的に処理し, 生物活性の変動
を観察した。その結果, $\mathrm{NH}_{2} \mathrm{OH}$ 処理の $\mathrm{ReGl}$ はほとん どの生物活性が失われるのに対して,弱塩酸処理の ReGl は一部の生物活性を保持して㧍り，それぞれの生物活性 の発現が ReGl の特定の構造を要求することが示唆され た。

\section{材料と方法}

\section{1. 材 料}

$\mathrm{ReGl}$ は Salmonella minnesota R 595 (Re 变異株) からフェノール：クロロホルム：石油エーテルで抽出し た5)。コードファクター (Cord factor; CF) は Mycobacterium bovis BCG から Noll と Bloch の方法9)で抽出 した。実験にはワックスCまで精製したものを使用し た。 


\section{ReGl のアルカリ処理}

ReGl の脱アシル化のために (A) エタノール中，0.1 $\mathrm{N}$ 水酸化ナトリウム, $37 \mathrm{C}, 30$ 分, (B) エタノール中, $2 \%$ アルカリ性 $\mathrm{NH}_{2} \mathrm{OH}, 65 \mathrm{C}, 5$ 分で処理を行つた。 中和後透析し, 遊離脂肪酸をク口ロホルムで抽出した。

(A) の生成物を ReGl- NaOH，(B) の生成物を ReGl$\mathrm{NH}_{2} \mathrm{OH}$ と略記する。

\section{ReGl の弱酸処理}

(A) $\mathrm{ReGl} 20 \mathrm{mM}$ 酰酸ナトリウム緩衝液 $(\mathrm{pH}$ 4.5)，100 C, 30分で処理した。反応物を透析後，超遠心 $(100,000 \times g ， 2$ 時間) で分離した $(\operatorname{ReGl}-\mathrm{pH} 4.5)$ 。

(B) ReGl $0.1 \mathrm{~N}$ 塩酸, $100 \mathrm{C}, 30$ 分反応させ, 遠心 $(3,000 \times g, 20$ 分) で沈殿後， 3 回蒸留水で洗浄した (ReGl-HCl)。

\section{4. 毒性測定およびリムルス活性測定}

鶏畉致死毒性 $\left(\mathrm{CELD}_{50}\right)$ 抢よび 発熱 毒性 $\left(\mathrm{FI}_{40}\right)$ は Milner と Finkelstein の方法8) で行つた。リムルス試 験はリムルステスト・ワコー (和光純薬) を用いて行つ た。試料は $0.5 \%$ トリエチルアミン水溶液 (パイロジェ ンフリー) に拡散させ, さらに $60 \mathrm{C} て ゙$ 数分加熱後, 超音 波洗浄器にて溶解させた溶液を生物活性試験に用いた (ReGl, ReGl-NaOH および ReG̣l- $\mathrm{NH}_{2} \mathrm{OH}$ はほほ透明 飞, ReGl-pH 4.5 抽よ゙ ReGl-HCl は乳白色になる)。

\section{5. マクロファージ活性化能測定}

$\mathrm{BALB} / \mathrm{c}$ マウスの腹腔内に $3 \%$ \%゚ロオース・ペプト ン水を $1 \mathrm{~m} l$ 投与し， 4 日後に浸出細胞を得た。 2 回洗 浄後, $10 \%$ 牛胎仔血清加 RPMI-1640 培地 (日水製薬) にて $2 \times 10^{6}$ 個 $/ \mathrm{m} l$ に調整し, ミクロタイタープレート (コースター社) に $100 \mu l$ づつ分注した。RL今1 (H-2d) 腫瘍細胞を $1 \times 10^{4}$ 個 $/ \mathrm{m} l$ と各試料液を $25 \mu l$ 加え 28 時 間培養した。次いで ${ }^{3} \mathrm{H}$-チミシシン(NEN 社) $1 \mu \mathrm{Ci} / 25 \mu l$ を加光，再び17時間培養後，ガラスフィルターでRL令1 細胞を集め, 放射能を液体シンチレーションカウンター で測定した。マクロファージ活性化能は腫瘍細胞の発育 阻止率で示した。

\section{6. リン八球幼若化能測定}

$\mathrm{BALB} / \mathrm{c}$ マウスの脾藏細胞を $5 \times 10^{6}$ 個 $/ \mathrm{m} l$ 亿調整し, ミクロタイタープレートに $200 \mu l$ 分注する。各試料を 培養液に溶解して $25 \mu l$ づつ加兄, 79時間培養し, ${ }^{3} \mathrm{H}-$ チミシシンを $1 \mu \mathrm{Ci} / 25 \mu l$ 加え, 再び17時間培養する。最 後にガラスフィルターで細胞を集め, 液体シンチレーシ ヨンカウンターで放射能を測定した。

\section{7. 抗腫䐗活性}

Wistar ラット (200 g 体重) の皮下にメチルコラント
レンを投与して得た線維肉腫（藤田浩ら，投稿準備中） を皮下継代した腫瘍細胞 $2 \mathrm{mg}$ をラットの側腹部皮下に 移植後 7 日目 $(8 \sim 13 \mathrm{~mm}$ 直径) に, 以下に述べる抗腫 瘍剛を $0.4 \mathrm{~m} l$ 腫瘍内に直接注射する。この注射を 7 日 扣きに 5 回行う。抗腫瘍剤は，基本的には ReGl (200 $\mu \mathrm{g})$ と CF $(100 \mu \mathrm{g})$ を $4 \mu \mathrm{l}$ の鉱物油（ドラケオール $6 \mathrm{VR}$ : ペンレコ社) と混合し, $400 \mu l$ の $0.2 \%$ Tween 80含有 PBS を加えてホモジナイザーで攂拌する11)。最 後に $65 \mathrm{C}, 30$ 分間加温し, 水中油の状態で使用する。担 癌ラットは完全退縮あるいは死亡の段階まで観察した。

\section{成 哴}

\section{1. 化学処理した ReGl の生物活性}

アルカリ拈よび弱酸で処理した ReGl の推定構造は天 野ら 2)が以前報告したS. typhimurium Re 変異株の ReGl を化学処理した生成物の化学組成と, 最近明らかにされ

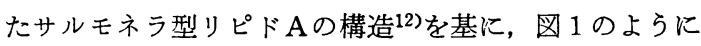
推定した。この推定構造はS. minnesota の ReGl と S. typhimurium の ReGl とがひとしいといら前提のも とに示した。アルカリ処理の場合, ReGlを $0.1 \mathrm{~N}$ 水 酸化ナトリウムで処理すると, 約半分の $o$-エステル結合 脂肪酸が脱離し ${ }^{2)}, \mathrm{NH}_{2} \mathrm{OH}$ で処理すると,すべての $0^{-}$ エステル結合脂肪酸とエタノールアミンリン酸が脱離す る。一方, $\mathrm{pH} 4.5$ の酢酸ナトリウムで処理すると, $\mathrm{KDO}$ とエタノールアミンリン酸が遊離し， $0.1 \mathrm{~N}$ 塩酸 処理すると，KDO，エタノールアミンリン酸抒よび還元 端のリン酸が遊離してくる。4-アミノアラビノースの存 在に関しては, Volk ら ${ }^{15}$ が $S$. minnesota $\operatorname{Re}$ 変異株の ReGl から分離しているが，われわれ1,2)は同株の ReGl からこの糖の存在を明らかにすることができなかつた。 このことはわれわれの使用した菌株の ReGl に実際に存 在していなかつたのか, あるいは検出できなかつたのか 明らかではない。表 1 にそれらの生物活性をまとめて示 した。リムルステストでは ReGl- $\mathrm{NH}_{2} \mathrm{OH}$ のみが非常に 低い活性を示している。以前に鷄卵致死毒測定および発 熱毒測定で無毒であることを示した $\mathrm{ReGl}-\mathrm{HCl}^{2)}$ は今回 の鷄卵致死毒測定でもほとんど活性がないことが確認さ れたが,リムルステストでは出発物質の ReGl とほとん ど変らぬ活性を有していることから, 以前より推測され ていたリムルス活性と毒性との相関関係は成立しないよ らに思われる。一方, 鶏卵致死毒性と発熱毒性との間に は相関関係を有することが以前の報告からも認められて おり，今回の実験からも支持された。ただし，ReGl-Na$\mathrm{OH}$ の鄓畉致死毒性に抢ける今回の測定值と以前の測定 

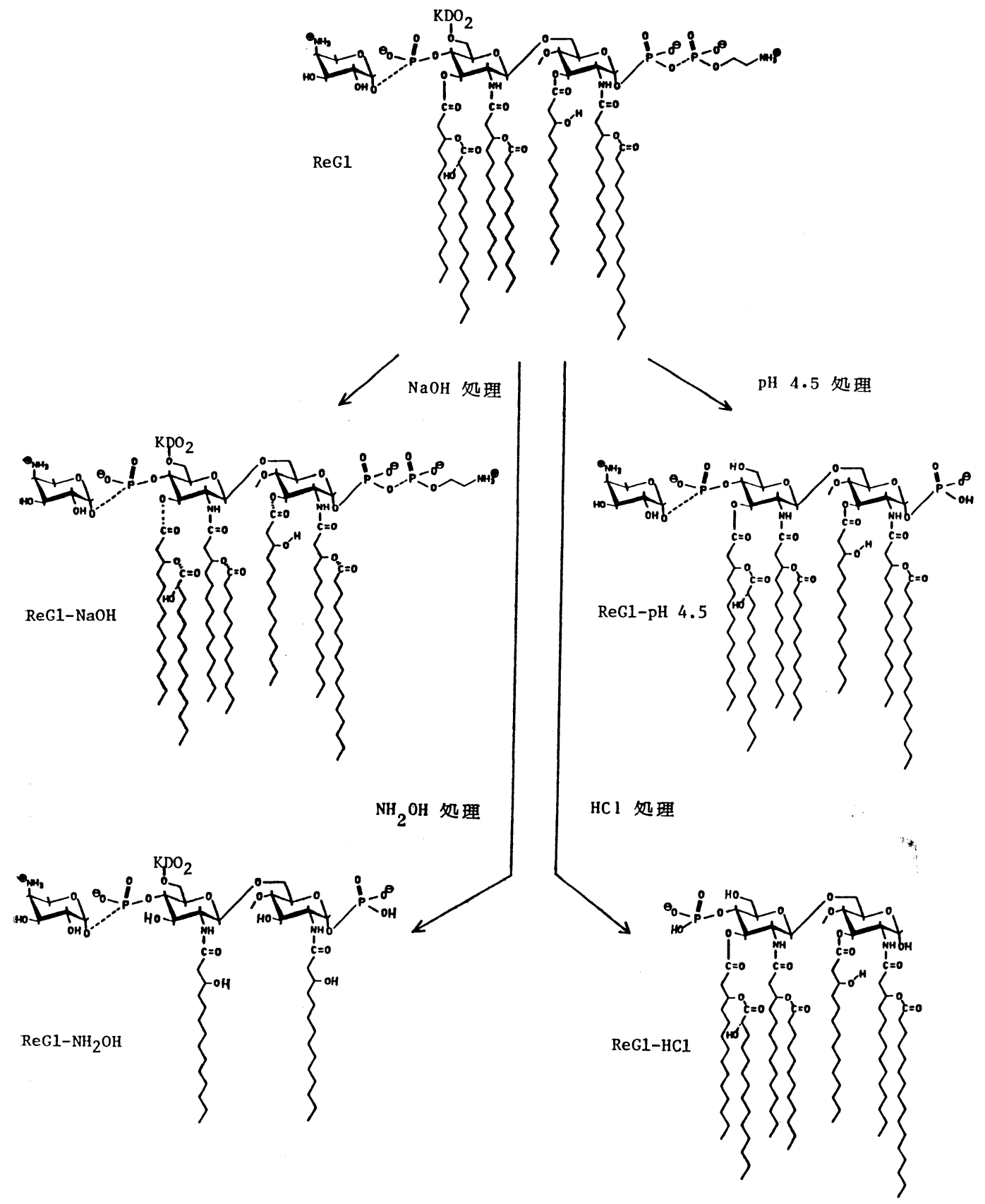

図 1. 化学処理した ReGl の推定構造.

点線の部分は不均一性を示している。特に ReGl- $\mathrm{NaOH}$ の場合, 以前の分析結果より1), O-エステ ル結合脂肪酸のちち, 約半分が脱離していると推定されている。 
表 1. 化学処理した $\operatorname{ReGl}$ の生物活性

\begin{tabular}{|c|c|c|c|c|c|}
\hline Sample & $\begin{array}{l}\text { Limulus test } \\
\text { M. E. C. }{ }^{a}(\mu \mathrm{g})\end{array}$ & $\begin{array}{c}\text { Lethality } \\
\text { CELD }_{50}(\mu \mathrm{g})\end{array}$ & $\begin{array}{l}\text { Pyrogenicity } \\
\mathrm{FI}_{40}(\mu \mathrm{g})\end{array}$ & $\begin{array}{l}\text { Macrophage } \\
\text { activation }\end{array}$ & Mitogenicity $^{c}$ \\
\hline ReGl & $5 \times 10^{-6}$ & $0.0220 .004^{d}$ & 0.76 & H & H \\
\hline $\mathrm{ReGl} \cdot \mathrm{NaOH}$ & $5 \times 10^{-6}$ & $0.24 \quad 0.0001^{d}$ & $\mathrm{ND}^{e}$ & \# & \# \\
\hline $\mathrm{ReGl}-\mathrm{NH}_{2} \mathrm{OH}$ & $5 \times 10^{-2}$ & $>10 \quad>10^{d}$ & $>20$ & \pm & - \\
\hline ReGl-pH 4.5 & $5 \times 10^{-5}$ & $\mathrm{ND}^{e} \quad 0.029^{d}$ & $\mathrm{ND}^{e}$ & H & + \\
\hline $\mathrm{ReGl}-\mathrm{HCl}$ & $5 \times 10^{-5}$ & $1.0^{d}$ & $>20$ & $H$ & \\
\hline
\end{tabular}
a, M. E. C.; 最少有効濃度
b，表 2 を要約した
c, 表 3 を要約した
d, Amano, et al., J. Biochem. 93, 1391 (1983) より引用した
e, ND; 未実験

表 2. ReGl のマクロファージ活性化能

\begin{tabular}{lrcc}
\hline Sample & $\begin{array}{c}\text { Dose } \\
(\mu \mathrm{g} / \mathrm{m} l)\end{array}$ & $\begin{array}{c}\text { 3H-dT } \\
\text { incorporation } \\
\left(\mathrm{cpm} \times 10^{-2}\right)\end{array}$ & $\begin{array}{c}\text { Inhibition } \\
(\%)\end{array}$ \\
\hline Control & 3 & $1,350 \pm 149$ & 0 \\
ReGl & 10 & $163 \pm 76$ & 87.9 \\
& 3 & $253 \pm 175$ & 81.3 \\
ReGl-NaOH & 10 & $63 \pm 7$ & 95.4 \\
& 3 & $1,074 \pm 156$ & 20.4 \\
ReGl-NH ${ }_{2} \mathrm{OH}$ & 10 & $889 \pm 6$ & 34.1 \\
& 3 & $52 \pm 17$ & 96.2 \\
ReGl-pH 4.5 & 10 & $164 \pm 108$ & 87.5 \\
& 3 & $383 \pm 163$ & 71.6 \\
ReGl-HCl & 10 & $261 \pm 9$ & 80.6 \\
& & & 96.1 \\
& 3 & &
\end{tabular}

值2)のくい違いは, 実験誤差やロット間の脂肪酸の遊離 量の差によることを推定させるが，理由は明らかでな い。免疫学的なファクターの一つであるマクロファージ 活性化能について検討してみると, ReGl- $\mathrm{NH}_{2} \mathrm{OH}$ はほ とんどこの活性を失つている一方, ReGl-HCl は元の ReGl に比べてわずかに低い值を示す程度の比較的強い 活性を保持していることが示された(表 2 )。リンパ球幼 若化能については表 3 に示されるよらに, ReG1 および ReGl-NaOH が高い活性を持ち, 特に ReGl-NaOH は 元の ReGl に比べてさらに活性化されており，その理 由として, 一部の脂肪酸が遊離することによつて, 水系 の溶媒に可溶化されやすくなつたためと考えられる。 ReGl-pH 4.5 は低いながらす活性を有しているが, $\mathrm{ReGl}-\mathrm{NH}_{2} \mathrm{OH}$ および ReGl-HCl はまつたくといつてよ いほど活性を失っている。
表 3. ReGl のリンパ球幼若化能

\begin{tabular}{|c|c|c|c|}
\hline Sample & $\begin{array}{l}\text { Dose } \\
(\mu \mathrm{g} / \mathrm{m} l)\end{array}$ & $\begin{array}{c}{ }^{3 \mathrm{H}} \cdot \mathrm{dT} \\
\text { incorporation } \\
\left(\mathrm{cpm} \times 10^{-2}\right)\end{array}$ & Ratio \\
\hline Control & & $26 \pm 4$ & 1.00 \\
\hline \multirow[t]{3}{*}{ ReGl } & 0.33 & $451 \pm 38$ & 17.4 \\
\hline & 3.3 & $732 \pm 35$ & 28.2 \\
\hline & 10 & $597 \pm 22$ & 23.0 \\
\hline \multirow[t]{3}{*}{$\mathrm{ReGl}-\mathrm{NaOH}$} & 0.33 & $818 \pm 17$ & 31.5 \\
\hline & 3.3 & $856 \pm 24$ & 32.9 \\
\hline & 10 & $1,160 \pm 105$ & 44.6 \\
\hline \multirow[t]{3}{*}{$\mathrm{ReGl}-\mathrm{NH}_{2} \mathrm{OH}$} & 0.33 & $33 \pm 2$ & 1.26 \\
\hline & 3.3 & $74 \pm 13$ & 2.85 \\
\hline & 10 & $27 \pm 6$ & 1.04 \\
\hline \multirow[t]{3}{*}{ ReGl-pH 4.5} & 0.33 & $32 \pm 6$ & 1.21 \\
\hline & 3.3 & $106 \pm 17$ & 4.08 \\
\hline & 10 & $223 \pm$ & 8.58 \\
\hline \multirow[t]{3}{*}{$\mathrm{ReGl}-\mathrm{HCl}$} & 0.33 & $26 \pm 6$ & 1.00 \\
\hline & 3.3 & $37 \pm$ & 1.41 \\
\hline & 10 & $60 \pm 3$ & 2.31 \\
\hline
\end{tabular}

$\mathrm{ReGl}-\mathrm{NaOH}$ と ReGl-pH 4.5 の構造と生物活性の比 較より, ReGl の部分的な脱 $o$-エステル化や，KDO の 脱離, およびエタノールアミンリン酸の脱離は, リムル ス活性, 鷄畉致死毒性扣よびマクロファージ活性化能に はほとんど影響を及ぼさないことが示唆され，反面 $\mathrm{KDO}$ およびエタノールアミンリン酸の脱離はリンパ球幼若化 能を低下させている。ReGl- $\mathrm{NH}_{2} \mathrm{OH}$ についての成績は, 完全な脱 の-エステル化が今回測定したすべての生物活性 を消失させるか, あるいは大幅に減少させることを示し 
ている。一方, ReGl-HCl の生物活性測定の結果は, 還 元端に存在するリン酸基の離脱扣よびもし存在するなら ば4-アミノアラビノースの離脱が毒性とリンパ球幼若化 能をほ注完全に消失させるのに対して, リムルス活性と マクロファージ活性化能を依然として残していることを 示している。

2. ReG1 のメチルコラントレン誘発ラット腫獋に対 する効果

これまでに Ribi らは Strain-2 モルモットの Line-10 肝癌に対する ReGl の抗腫瘍性を検討しており, 高率に 治瘾させることを報告している2,10)。今回われわれはモ ルモット以外の動物腫瘍に対する ReGl の効果を明らか にするために, メチルコラントレン投与によつてラット の皮下に発生した肉腫を移植継代し，その腫瘍に対して ReGl の投与を行つた。予備実験として ReGl の投与量 を変えて行つたところ，400 $\mu \mathrm{g}$ および $600 \mu \mathrm{g}$ の投与量 ではほとんど非投与群と変らず，200 $\mu \mathrm{g}$ では $20 \%$ の治 瘾率および非投与群に対して約 2 倍の延命効果が見られ たので (藤田浩ら，投稿準備中)，以降の抗腫瘍実験では ReGl およびその化学処理物質は $200 \mu \mathrm{g}$ を用いた。ReGl を $400 \mu \mathrm{g}$ 抢よび $600 \mu \mathrm{g}$ に增量した場合に治瘾効果が 見られなかつたのは， ReGl の直接的な細胞障害性その ほかの毒性に基づくと考えられ，この見地からす ReGl の無毒化処理が必要であると考えられた。四2 2 は種々の 組合せによる効果を見た実験で，ReGl と CF (100 $\mu \mathrm{g})$ の混合物では60\%の治瘾率を示し， ReG1 単独では非投 与群に比較して1.64倍の延命効果が見られたが，治瘾し たラットはいなかつた(表 4)。CF 単独では非投与群と
表 4. $\operatorname{ReGl}$ のメチルコラントレン誘発ラット腫㾤 に対する効果

\begin{tabular}{lcc}
\hline Sample & $\begin{array}{c}\text { Tumor regression } \\
\text { No. cured/No. } \\
\text { total }(\%)\end{array}$ & $\begin{array}{c}\text { Survival average } \\
\text { of died rats } \\
\text { (days (rate) }\end{array}$ \\
\hline Control & $0 / 4(0)$ & $39(1.00)$ \\
$\mathrm{ReGl}+\mathrm{CF}$ & $3 / 5(60)$ & $56(1.44)$ \\
$\mathrm{ReGl}$ & $0 / 5(0)$ & $64(1.64)$ \\
$\mathrm{CF}$ & $0 / 4(0)$ & $52(1.33)$ \\
$\mathrm{ReGl}-\mathrm{NH}_{2} \mathrm{OH}+\mathrm{CF}$ & $0 / 5(0)$ & $67(1.72)$ \\
$\mathrm{ReGl}-\mathrm{HCl}+\mathrm{CF}$ & $2 / 4(50)$ & $47(1.21)$ \\
\hline
\end{tabular}

ほとんど変らず，無効と判定した。図3では化学処理し た ReGl の抗腫場効果を比較した。その結果, ReGl-HCl は50\%の治瘾効果を示し，未処理の $\mathrm{ReGl}$ と同様の抗腫 瘍活性が見られた。また ReGl- $\mathrm{NH}_{2} \mathrm{OH}$ に関しては,治 瘾したラットは見られなかつたものの, 非投与群に対し て1.72倍といら高い延命効果が見られたことは， ReGl$\mathrm{NH}_{2} \mathrm{OH}$ にも低いながら抗腫瘍活性が存在することを示 している。

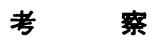

Strain-2 モルモットの Line-10 肝癌という特殊な条 件での LPS の抗腫瘍効果がいくつかの研究室 $2,3,10.11$ で 観察されているが，それ以外の腫癔に対する LPS の効 果に関する報告は意外に少なく，LPS が普遍的に抗腫 瘍活性を有するかどらか明らかではなかつた。今回われ われはラットのメチルコラントレン誘発腫瘍に対するサ

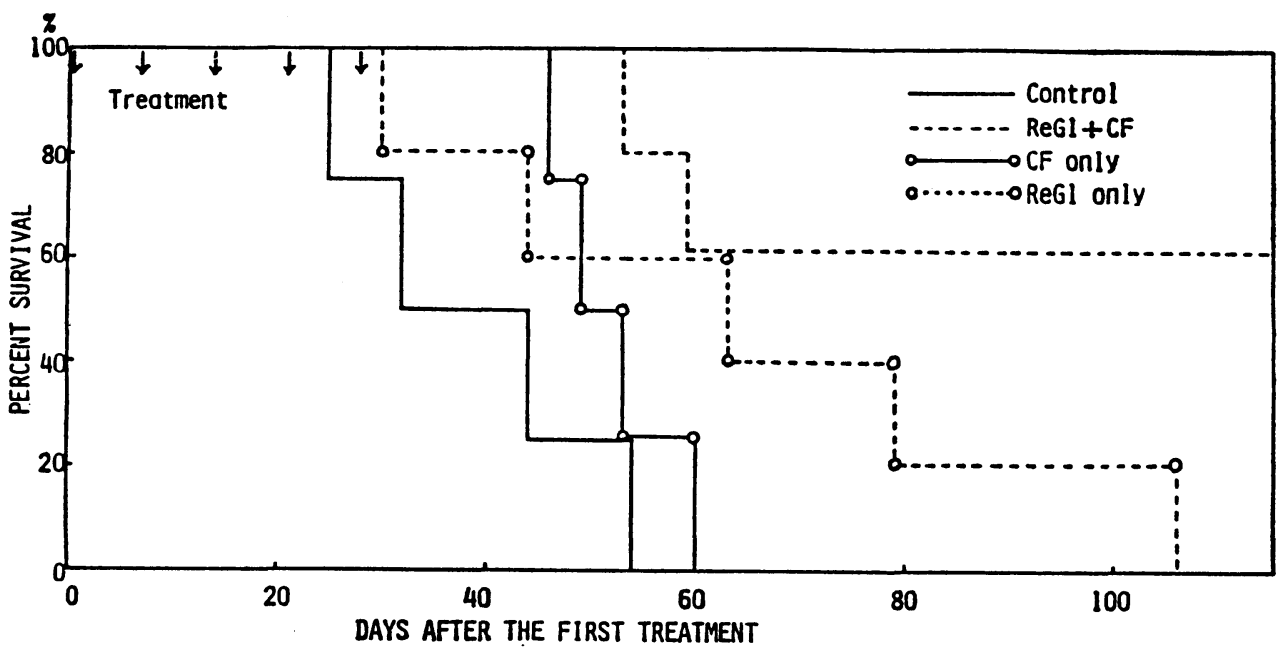

図 2. メチルコラントレン誘発ラット肉腫の移植腫㾤に対する ReGl と CF の組み合せによる効果. 


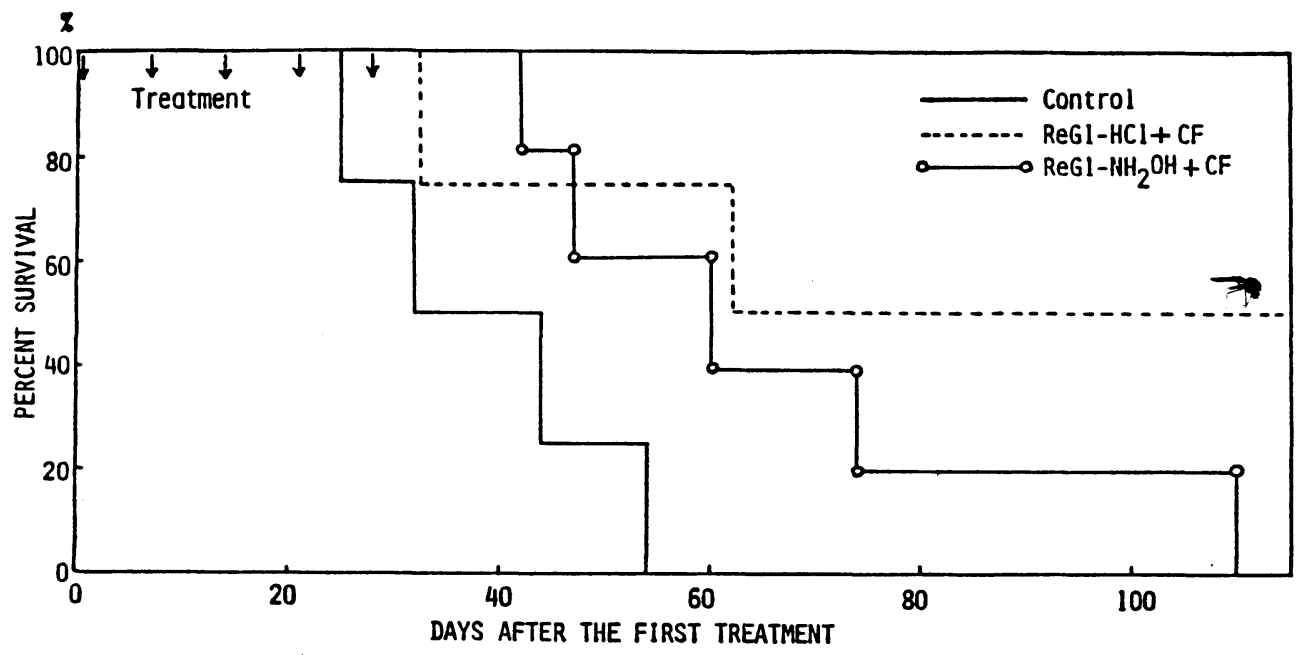

図 3.メチルコラントレン誘発ラット肉腫の移植腫瘍に対する化学処理した ReGl の効果.

ルモネラ $\operatorname{Re}$ 変異株の内毒素である糖脂質 $(\mathrm{ReGl})$ の抗 腫瘍奻果を観察し, その場合にも CF の共存が必要であ りなおかつ水中油の状態で腫瘍内へ投与することが必 要であることを明らかにした。こうした投与条件の限定 が臨床応用を試みる場合の障害となつてくる。今後この 点について検討しなければならない。

もら一つの大きな障害である LPS の毒性に関しては， 1981年以降, Ribi ら 2 10,13)がサルモネラ Re 変異株由来 糖脂質の弱酸処理 $(\mathrm{pH} 4.5$ の酢酸ナトリウム, EDTA, $0.1 \mathrm{~N}$ 塩酸) によつて毒性の 無いリピド $\mathrm{A}$ 部分を分離 し, この化合物が Strain-2 モルモットの Line-10 肝癌 に対する抗腫瘍活性を保持していることを示した。この 場合には㲕卵致死毒性と発熱毒性を測定しており, リム ルステストでは測定していなかつた。今回, 化学処理し た ReGl を上記の方法で測定し，その結果を比較したと ころ, ReGl-HCl には依然としてリムルス活性が残つて おり，この糖脂質ではりムルステストとほかの毒性測定 法の間には相関関係のないことが明らかになつた。この 結果は以前に棚元と本間14)によつて報告されたと同様 に，毒性とリムルス活性の相関性については，すべての 物質にはあてはまらないことを示している。

われわれはこの無毒化した ReGl-HCl を用い，上記に 示したラットのメチルコラントレン誘発腫瘍に対する奻 果を観察したところ，未処理の ReGl と同様の抗腫瘍活 性を示すことを見いだした。 ReGl-HCl は依然としてマ クロファージ活性化能を残しており，この活性が抗腫瘦 性発現の一翼を担つている可能性があるが，まだ明らか
ではない。一方，全部の $o$-エステル結合脂肪酸を除いた $\mathrm{ReGl}-\mathrm{NH}_{2} \mathrm{OH}$ は，今回の実験ではすべての生物活性を 失い，抗腫瘳活性は延命効果のみで，比較的弱い活性し

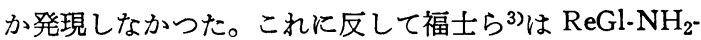
$\mathrm{OH}$ による Strain-2 モルモットの Line-10 腫瘍に対し てかなり有効であると報告しており，今回の結果とくい 違いが見られる。その理由としては使用した動物種の違 い(モルモットとラット), 腫瘍の違い(肝癌と線維肉腫) および ReGl- $\mathrm{NH}_{2} \mathrm{OH}$ のロットの違いなどが考兄られる が，今のところ明らかではない。

これらの化学処理した ReGl から得られた実験成績

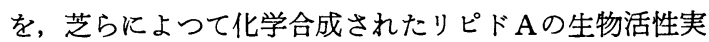
験結果 $4,6,7)$ と直接比較することは, 現段階では必ずしる 適切ではないけれども，われわれの $\mathrm{ReGl}-\mathrm{HCl}$ と芝らの 合成化合物 404 ( 2 と 2 ' のアミ) 基と 3 と 3 ' の水酸基に $\beta$-ヒドロキシミリスチン酸が結合，4'の水酸基にリン酸 基が結合しているグルコサミン二糖）がリン酸の結合位 置を含めた構造で類似して打り，生物活性についても， リムルス活性が強く，毒性と発熱性が弱いといら点で一 致している。将来 double acyl 体のリピドAが化学合成

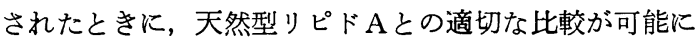
なると思われ，化学合成からのアプローチは今後ますま す重要性を増すであろう。しかしながら細菌菌体から抽 出した内毒素は量的に入手しやすく，大量の材料で研究 を行えるという利点を考学ると，抽出内毒素を用いる研 究は今後す必要性を失わないと思われる。 


\section{文献}

1) Amano, K. and Fukushi, K. (1984) : Chemical and ultrastructural differences in endotoxic glycolipids from Salmonella minnesota Re mutant extracted with various solvent systems. Microbiol, Immunol. 28, 135-148.

2) Amano, K., Ribi, E., and Cantrell, J. L. (1983) : Structural requirements of endotoxic glycolipid for antitumor and toxic activity. J. Biochem. 93, 1391-1399.

3) Fukushi, K., Asano, H., and Sasaki, J. (1982) : Antitumor activity of deacylated Salmonella endotoxin combined with trehalose dimycolate. 395-398, In Immunomodulation by microbial products and related synthetic compounds, Yamamura, Y., Azuma, I., Koda, A., and Shiba, T. (eds.), Excerpta Medica, Amsterdam.

4) Galanos, C., Lehmann, V., Lüderitz, O., Rietschel, E. Th., Westphal, O., Brade, H., Brade, L., Freudenberg, M. A., Hansen-Hagge, T., Lüderitz, T., McKenzie, G., Schade, U., Strittmatter, W., Tanamoto, K., Zähringer, U., Imoto, M., Yoshimura, H., Yamamoto, M., Shimamoto, T., Kusumoto, S., and Shiba, T. (1984) : Endotoxic properties of chemically synthesized lipid A part structures. Comparison of synthetic lipid A precursor and synthetic analogues with biosynthetic lipid A precursor and free lipid A. Eur. J. Biochem. 140, 221-227.

5) Galanos, C., Lüderitz, O., and Westphal, O. (1969): A new method for the extraction of $\mathrm{R}$ lipopolysaccharides. Eur. J. Biochem. 9, 245-249.

6) Kanegasaki, S., Kojima, Y., Matsuura, M., Homma, J. Y., Yamamoto, A., Kumazawa, Y., Tanamoto, K., Yasuda, T., Tsumita, T., Imoto, M., Yoshimura, H., Yamamoto, M., Shimamoto, T., Kusumoto, S., and Shiba, T. (1984): Biological activities of analogues of lipid A based chemically on the rivised struc. tural model. Comparison of mediator-inducing, immunomodulating and endotoxic activities. Eur. J. Biochem. 143, 237-242.

7) Kotani, S., Takada, H., Tsujimoto, M., Ogawa, T., Harada, K., Mori, Y., Kawasaki, A., Tanaka, A., Nagao, S., Tanaka, S., Shiba, T., Kusumoto, S., Imoto, M., Yoshimura, H.,
Yamamoto, M., and Shimamoto, T. (1984): Immunobiologically active lipid $\mathrm{A}$ analogs synthesized according to a revised structural model of natural lipid A. Infect. Immun. 45, 293-296.

8) Milner, K. C. and Finkelstein, R. A. (1966) : Bioassay of endotoxin: Correlation between pyrogenicity for rabbits and lethality for chick embryos. J. Infect. Dis. 116, 529-536.

9) Noll, H. and Bloch, H. (1955): Studies on the chemistry of the cord factor of Mycobacterium tuberculosis. J. Biol. Chem. 214, 251265.

10) Ribi, E., Amano, K., Cantrell, J. L., Schwartzman, S., Parker, R., and Takayama, K. (1982) : Preparation and antitumor activity of nontoxic lipid A. Cancer Immunol. Immunother. 12, 91-96.

11) Ribi, E., Takayama, K., Milner, K. C., Gray, G. R., Goren, M., Parker, R., McLaughlin, C. A., and Kelly, M. (1976) : Regression of tumors by an endotoxin combined with trehalose mycolate of differing structure. Cancer Immunol. Immunother. 1, 265-270.

12) Rietschel, E. Th., Sidorczyk, Z., Zähringer, U., Wollenweber, H., and Lüderitz, O. (1983) : Analysis of the primary structure of lipid A. 195-218, In Bacterial lipopolysaccharides: Structure, synthesis, and biological activities, Anderson, L. and Unger, F. M. (eds.), ACS Symposium Series 231, American Chemical Society, Washington, D. C.

13) Takayama, K., Ribi, E., and Cantrell, J. L. (1981) : Isolation of a nontoxic lipid A fraction containing tumor regressive activity. Cancer Res. 41, 2654-2657.

14) Tanamoto, K. and Homma, Y. (1982): Essential regions of the lipopolysaccharide of Pseu. domonas aeruginosa responsible for pyrogenicity and activation of the proclotting enzyme of horseshoe crabs. Comparison with antitumor, interferon-inducing and adjuvant activities. J. Biochem. 91, 741-746.

15) Volk, W. A., Galanos, C., and Lüderitz, O. (1970): The occurrence of 4-amino-4-deoxy-Larabinose as a constituent in Salmonella lipopolysaccharide preparations. Eur. J. Biochem. 17, 223-229. 


\title{
Biological activities of chemically-treated glycolipids from Salmonella minnesota Re-mutant
}

\author{
Ken-ichi AMANO, Hiroshi FUJITA*, Toshinobu SATO*, \\ Hiromi SASAKI*, Yutaka YOSHIDA*, and Kazue FUKUSHI \\ Department of Bacteriology and *First Department of Internal Medicine, \\ Hirosaki University School of Medicine, Hirosaki, Aomori 036
}

Endotoxic glycolipid (ReGl) extracted from the heptose-less Re mutant of Salmonella minnesota was hydrolyzed with each of alkali or acid reagents, and the products were analyzed for several biological activities. Treatment of $\mathrm{ReGl}$ with $\mathrm{NH}_{2} \mathrm{OH}$ caused the liberation of all $O$-ester-linked fatty acids resulting in abrogation of toxicity (lethality to chick embryos), pyrogenicity, activity of Limulus amoebocyte lysate (LAL) gelation, ability of macrophage activation, and mitogenicity. ReGl treated with $\mathrm{HCl}$, which splits off $\mathrm{KDO}$ and glycosidic phosphate, retained only two biological activities (LAL gelation activity and ability of macrophage activation). $\mathrm{NaOH}$-treated or $\mathrm{CH}_{3} \mathrm{COONa}$-treated $\mathrm{ReGl}$ possessed similar activities to those of untreated ReGl.

On the other hand, $\mathrm{ReGl}$ or $\mathrm{ReGl}-\mathrm{HCl}$, in combination with cord factor, showed effectively regressive activities (about 50\% cures) to the methylcholanthrene-induced tumor of rats, while $\mathrm{ReGl}-\mathrm{NH}_{2} \mathrm{OH}$ showed only prolongation of life in compariscn with that of tumor-bearing rats without treatment. 